\title{
Horseshoe Bats (Chiroptera, Rhinolophidae) in the south-western Crimea and problems of their protection
}

\author{
llya S. Turbanov* \& Alexander N. Ivanitsky
}

\begin{abstract}
Largely based on original data, the distribution and abundance of Rhinolophidae in southwestern Crimea are updated and summarized, with only two species involved - Rhinolophus hipposideros and $R$. ferrumequinum. Their colonies, both wintering and maternity, have been found. Several breeding colonies of $R$. ferrumequinum have been recorded for the first time at and near Sevastopol. A total of 24 and 32 shelters and roosts of $R$. hipposideros and $R$. ferrumequinum have been registered in the study region, respectively. The main factors affecting Horseshoe bat occurrences and conservation in south-western Crimea are outlined as well.

How to cite this article: Turbanov I.S., Ivanitsky A.N. 2018. Horseshoe Bats (Chiroptera, Rhinolophidae) in the south-western Crimea and problems of their protection // Russian J. Theriol. Vol.17. No.1. P.39-47. doi: $10.15298 /$ rusjtheriol.17.1.04
\end{abstract}

KEY WORDS. Rhinolophus hipposideros, Rhinolophus ferrumequinum, south-western Crimea, caves, distribution, abundance, species protection.

Ilya S. Turbanov [turba13@mail.ru], Papanin Institute of the Biology of Inland Waters, Russian Academy of Sciences, Borok, Nekouzskiy District, Yaroslavl Region, 152742, Russia; Cherepovets State University, Lunacharskogo pr., 5, Cherepovets, Vologda Region, 162600, Russia; Alexander N. Ivanitsky [nathusii@mail.ru], Vyazemski Karadag Research Station - Nature Reserve, Russian Academy of Sciences, Nauki Str., 24, Kurortnoe, Feodosia, Republic of Crimea, 298188, Russia.

\section{Подковоносы (Chiroptera, Rhinolophidae) Юго-Западного Крыма и проблемы их охраны}

\section{И.С. Турбанов*, А.Н. Иваницкий}

\begin{abstract}
РЕЗЮМЕ. В статье приводятся оригинальные данные, а также обобщаются все известные сведения о распространении и численности подковоносов (Rhinolophidae) в Юго-Западном Крыму, которые представлены двумя видами - Rhinolophus hipposideros и R. ferrumequinum. В описываемом регионе найдены как зимовочные, так и выводковые колонии обоих, обитающих здесь видов. Выводковая колония $R$. ferrumequinum в Севастополе и на сопредельных территориях впервые отмечена нами. Всего в исследуемом регионе зарегистрировано 24 убежища $R$. hipposideros и $32-R$. ferrumequinum. В работе рассматриваются также лимитирующие факторы для подковоносов Юго-Западного Крыма, а также вопросы охраны этих животных.
\end{abstract}

КЛЮЧЕВЫЕ СЛОВА. Rhinolophus hipposideros, Rhinolophus ferrumequinum, Юго-Западный Крым, пещеры, распространение, численность, охрана видов.

\section{Introduction}

The study of Horseshoe bats in south-western Crimea enjoys a history of more than a century (Brauner, 1911; Lebedev, 1912, 1914; Konstantinov et al., 1976; Dulitsky \& Kovalenko, 2003; Denisova \& Amelichev, 2005; Amelichev, 2008; Godlevskaya et al., 2009; Amelichev \& Klimchuk, 2010; Matyushkin, 2010a,b; Turbanov et al., 2015). At the same time, the available published information still remains highly fragmented and incomplete, and offers limited information concerning the present distribution, abundance and ecology of Horseshoe bats in the region.

* Corresponding author
The Horseshoe bat family Rhinolophidae Gray, 1825 (Mammalia: Chiroptera) is globally represented by at least 70-80 species (Csorba et al., 2003; Simmons, 2005) predominantly inhabiting the tropical and subtropical parts of the Old World, with only a few extending into temperate areas and mainly occurring there in regions with a relatively mild winter. The northern range limit of Horseshoe bats in the Black Sea region lies in Crimea, approximately at a latitude of $45^{\circ} 30^{\prime} \mathrm{N}$.

For the Crimean Peninsula generally and its southwestern part in particular the occurrence of only two species of this family have been confirmed: Rhinolophus hipposideros (Bechstein, 1800) and R. ferrumequinum (Schreber, 1774). The former species has been reported from south-western Crimea since the early $20^{\text {th }}$ 


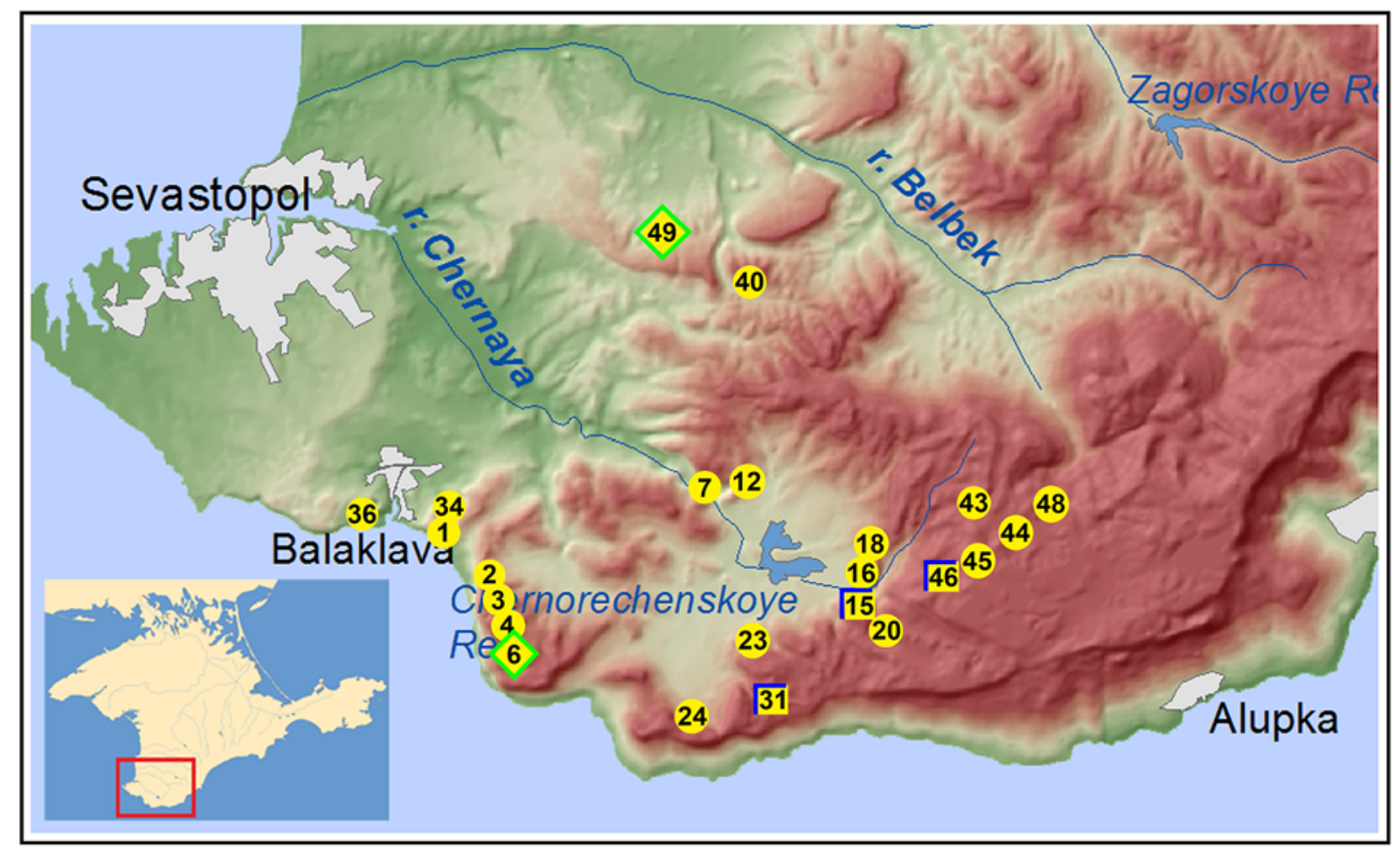

Fig. 1. Distribution of the Lesser Horseshoe bat (R. hipposideros) in south-western Crimea. The number inside the marks (circle - the site of the finds; square - maternity colony, rhombus - wintering record) corresponds to that of the $R$. hipposideros shelter in Tabs 1-3.

century (Brauner, 1911); the latter one was first recently observed in October 1999 (Denisova \& Amelichev, 2005). However, both these species are known to have occurred in the Crimean Peninsula much earlier, at least since the second half of the $19^{\text {th }}$ century. $R$. ferrumequinum has been documented there in 1856 , based on the collection of Christian von Steven kept in the Zoological Institute of the Russian Academy of Sciences in St. Petersburg (ZIN) (Dulitsky \& Kovalenko, 2003). This corresponds well to the time of the first catches of other bat species in Crimea and suggests the historic presence of these species in the region, rather than their recent introductions due to range expansion.

Two other species of Horseshoe bats, R. euryale Blasius, 1853 and $R$. mehelyi Matschie, 1901, have erroneously been recorded from Crimea (Zagorodniuk, 1999; Dulitsky et al., 2001), but both of these records are likely a result of misidentifications. Finding these two latter species in Crimea is quite doubtful, as their nearest reliable records come from very distant areas: $R$. euryale is known from as far as the south of the Krasnodar Territory, Russian Federation, i.e. over 220 $\mathrm{km}$ direct flight distance across the Black Sea (Gazaryan \& Ivanitsky, 2005; Gazaryan, 2007), while the most proximate records of $R$. mehelyi are from the Black Sea regions of Romania, also several hundred $\mathrm{km}$ away (Nagy \& Postawa, 2010). These species are non-migratory, the maximum distance records they are known to seasonally travel being some $134 \mathrm{~km}$ in the eastern
Pyrenees for R. euryale (see Heymer, 1964) and $94 \mathrm{~km}$ in Bulgaria for R. mehelyi (Dietz et al., 2009).

\section{Material and methods}

Material for the present paper was obtained in the course of original annual studies conducted from 2009 to 2017 in caves and artificial underground structures located within the Sevastopol City and the neighbouring Bakhchisaray District of the Republic of Crimea. In addition, all known literature data concerning the bats of the above territories were reviewed, and information obtained from speleologists and spelestologists was surveyed to identify new, previously unknown shelters or roosts of Horseshoe bats.

Bats were studied without catching them through their daytime visual records and counts in caves and various artificial underground structures. Our earlier surveys were carried out almost throughout the year, including winter. The last, almost continuous inspection was undertaken during the summer of 2017 as part of a more general project aimed at monitoring the wildlife objects listed in the Red Data Book of the city of Sevastopol. As that most recent survey covered nearly all previously identified shelters and roosts of Horseshoe bats in south-western Crimea, it has allowed us not only to obtain new data, but also to refine and update all available information on their distribution, numbers and locations in the region concerned. 


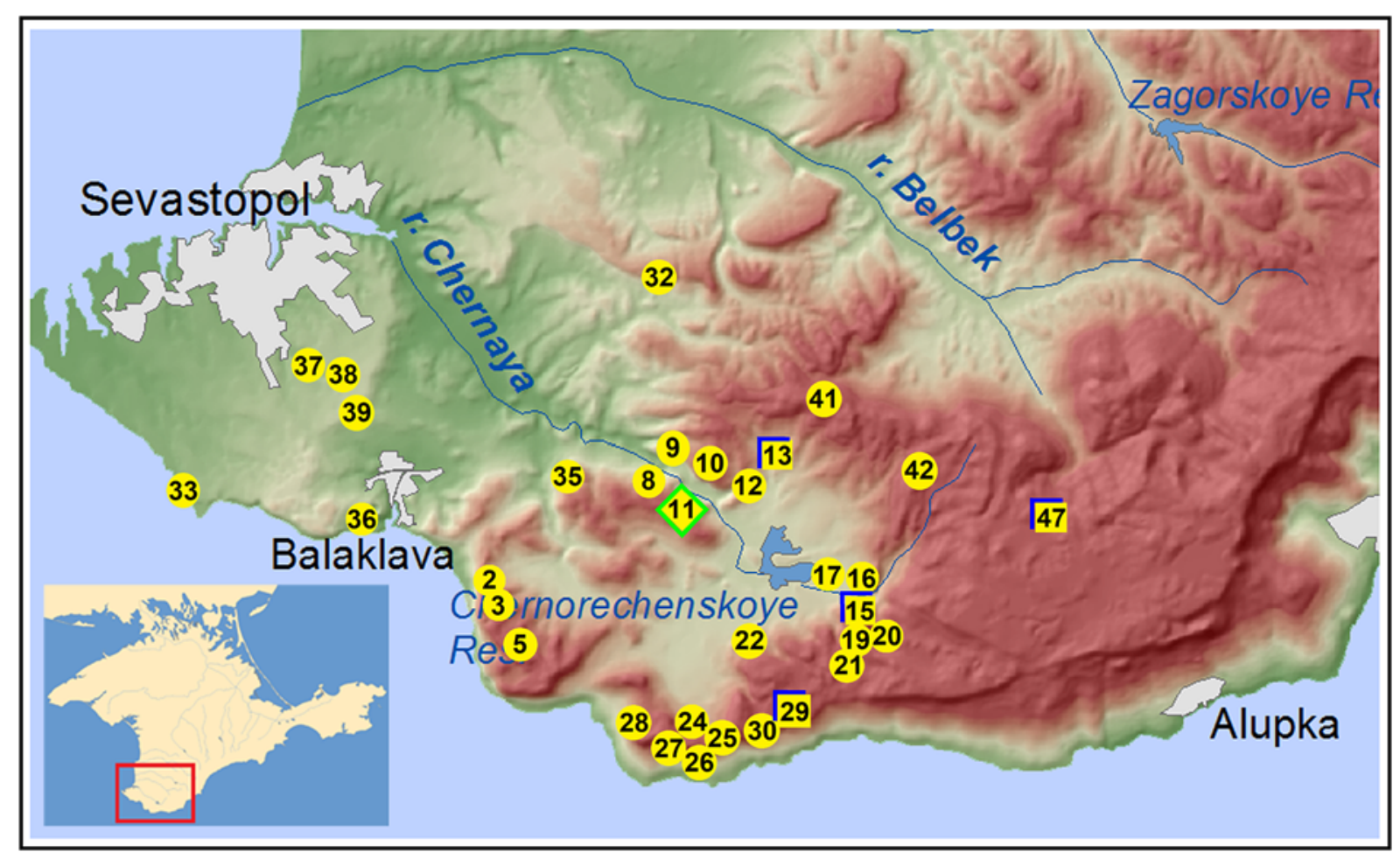

Fig. 2. Distribution of the Great Horseshoe bat (R. ferrumequinum) in south-western Crimea. The number inside the marks (circle - the site of the finds; square - maternity colony; rhombus - wintering record) corresponds to that of the $R$. ferrumequinum shelter in Tabs 1-3.

\section{Results and Discussion}

The original research 2009-2017 and an analysis of the literature make it possible to get a relevant picture of the current distribution and abundance of $R$. hipposideros and $R$. ferrumequinum in entire south-western Crimea. Unfortunately, some literature data are deficient in species determination, e.g. the report on the Horseshoe bats of the Karan-Koba Cave near the Village of Peredovoye (see Matyushkin, 2010a).

Shelters and roosts. According to the "Caves" information retrieval system which represents a survey of the caves of Russia and neighbouring countries (see Appendix 1), the Sevastopol region supports 125 caves, while about another 150 caves are located in the adjacent territories. However, this survey is still in an early stage of development, as the number of caves is actually much higher.

To date, Horseshoe bats have been registered in 39 shelters (32 natural caves and 7 artificial structures) in the study area. The known shelters and roosts of Horseshoe bats in south-western Crimea are listed in tables 1-3 and also shown on schematic maps (Figs 1, 2).

Rhinolophus hipposideros. To date, $R$. hipposideros has been identified in 24 shelters in south-western Crimea, including 15 caves and 2 artificial dungeons of Sevastopol, as well as 7 shelters in the adjacent territories in the Republic of Crimea (Tabs 1-3, Figs 1, 3A).

Hibernating colonies were found within the two caves - Raskop Medvezhiy (Matyushkin, 2010b, 2012) and Egerskaya II (original unpublished data). Maternity colonies of $R$. hipposideros were recorded in niches of the ancient settlement of Eski-Kermen (Konstantinov et al., 1976), as well as in the Gekkonovaya Cave (original unpublished data). Unfortunately, some of the literature information concerning the study region was accompanied by neither an exact date and nor a reproductive status of the animals. Perhaps some of these data also apply to wintering or nursery colonies. Thus, for example, a cluster of 10 individuals of $R$. hipposideros found on May 2nd of 2006 in the Raskop Medvezhiy Cave (Matyushkin, 2010b, 2012) was probably a maternity colony. The number of hibernating animals per shelter varied from 1 to 8 individuals, maternity colonies formed in both cases contained 9 females, in one case two females were already with newborns. A similar number of hibernating bats per shelter was observed in other Black Sea regions - in Abkhazia (Ivanitsky \& Smirnov, 2016), Romania (Nagy \& Postawa, 2010), Bulgaria (Benda et al., 2003), where winter shelters accumulated up to a dozen or ever a little more individuals. Maternity colonies of $R$. hipposideros in other regions were located in buildings, as a rule: basements, attics, etc. (Rakhmatulina, 2005; Ivanitsky \& Smirnov, 2016). Natural caves are not a typical place for the breeding colonies of this species, although there are known records of such colonies from caves and from other regions, particularly Transcaucasia (Rakhmatulina, 2005; Ivanitsky, 2017). Several larger colonies can be formed in artificial structures, usually 20 
Table 1. List of shelters of Horseshoe bats in caves of the Sevastopol City with original data.

\begin{tabular}{|c|c|c|c|}
\hline $\mathrm{No}^{*}$ & Shelter & R. hipposideros & R. ferrumequinum \\
\hline 1. & Asketi & 31.07.2017-2 ind. [1] ${ }^{* *}$ & - \\
\hline 2. & Dvukhkupolnaya & $\begin{array}{l}\text { 27.06.2017-2 ind., } \\
\text { 30.07.2017-3 ind. [1] }\end{array}$ & $\begin{array}{l}\text { 27.06.2017-2 ind., } \\
30.07 .2017-2 \text { ind. [1] }\end{array}$ \\
\hline 3 & Arochnaya & $\begin{array}{l}\text { 27.06.2017-3 ind., } \\
30.07 .2017-3 \text { ind. [1] }\end{array}$ & $\begin{array}{l}\text { 27.06.2017- } 1 \text { ind., } \\
\text { 30.07.2017-2 ind. [1] }\end{array}$ \\
\hline 4. & Bely Brat & 27.06.2017 - 1 ind. [1] & - \\
\hline 5. & Kalafatlar-Kobasy & - & 27.06.2017 - 4 ind. [1] \\
\hline 6. & Gekkonovaya & $\begin{array}{c}\text { 27.06.2017 - } 11 \text { ind. (n.c. }-9 \text { 9P+, } 2 \\
\text { juv.) }+[1]\end{array}$ & - \\
\hline 7. & Kara-Koba & 5.07.2017-3 ind. [1] & $\begin{array}{lllllllllllllll}- & \end{array}$ \\
\hline 8. & Tshernorechenskaya & - & $5.07 .2017-5$ ind. [1] \\
\hline 9. & Tomenko & - & 5.07.2017-2 ind. [1] \\
\hline 10. & Karshi-Kaya-Koba & - & 5.07.2017-1 ind. [1] \\
\hline 11. & Langa-Kaya-Koba & - & $\begin{array}{c}5.07 .2017-25-30 \text { ind. } \\
\text { (n.c.) }+[1]\end{array}$ \\
\hline 12. & Anny & $21.10 .1999-2$ ind. [5] & 21.10.1999-4 ind. [5] \\
\hline 13. & Eldorado & - & Dec $2003-7$ ind.^ [5] \\
\hline 14. & Karan-Koba & Several [10] & Several [10] \\
\hline \multirow{7}{*}{15.} & \multirow{7}{*}{ Skelskaya } & Several $[4,9]$ & 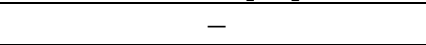 \\
\hline & & Solitary $O^{7} O^{7}[7]$ & - \\
\hline & & $4.09 .2004-1$ ind. [5] & $4.09 .2004->10$ ind. [5] \\
\hline & & 5-7 ind. (summer) [2] & $20-30$ ind. (summer) [2] \\
\hline & & 16.06.2006-2 ind. [6] & 16.06.2006 - 2 ind. [6] \\
\hline & & $5.05 .2017-\mathrm{No}, \mathrm{fi}$ & 1 guano [1] \\
\hline & & 10.07.2017 - 1 ind. [1] & 10.07.2017 - 2 ind. [1] \\
\hline 16. & Entuziastov & 5.05.2017 - 1 ind. [1] & $5.05 .2017-1$ ind. [1] \\
\hline 17. & Tshernaya & - & 5.05.2017 -2 ind. [1] \\
\hline \multirow{2}{*}{18.} & \multirow{2}{*}{ Myshinaya } & Many $[8,9]$ & - \\
\hline & & 19.07.2017-3 ind. [1] & - \\
\hline 19. & $\begin{array}{l}\text { 40 Let Sevastopolskoy } \\
\text { Speleologii }\end{array}$ & - & 5.07.2017 - 2 ind. [1] \\
\hline 20. & Tainstvennaya & 5.07.2017 - 2 ind. [1] & 5.07.2017 - 2 ind. [1] \\
\hline 21. & Nassonova & - & $5.05 .2017-1$ ind. [1] \\
\hline 22. & Baydar-Tshokrak & - & 2.07.2017-2 ind. [1] \\
\hline 23. & Sakhtykh & 11.08 .2012 - small colony [13] & - \\
\hline 24. & Mamut-Tshokrak & 6.05.2012 - 4 ind. (dead) $[1]$ & 2.07.2017 - 2 ind. [1] \\
\hline \multirow{2}{*}{25.} & \multirow{2}{*}{ Biyuk-Tekne-Bel } & - & 26.04.2011 - 1 ind. [1] \\
\hline & & - & $2.07 .2017-\mathrm{No}[1]$ \\
\hline 26. & Forosskaya & - & 25.06.2017-5 ind. [1] \\
\hline 27. & Baydarskaya & - & 25.06.2017 - 1 ind. [1] \\
\hline 28. & Machuk & 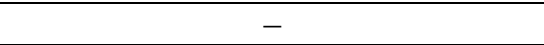 & 25.06.2017 - 2 ind. [1] \\
\hline 29. & Zhemchuzhnaya & - & $2011-14-1-5$ ind. $\wedge^{[}[1]$ \\
\hline 30. & Gravitsapa & - & $\begin{array}{c}\text { March-Apr } 2012-3-5 \text { ind. } \\
{[1]}\end{array}$ \\
\hline 31. & Egerskaya II & $4.02 .2011-3$ ind.^ $[1]$ & - \\
\hline
\end{tabular}

Notes: ind. — individuals; $\bigcirc^{\top} \bigcirc^{\top}-$ males; $\stackrel{+}{+}$ — females; juv. — juvenile; n.c. — maternity colony; ${ }^{\wedge}$ — wintering record; ${ }^{+}$— breeding record; * - number of the locality (see Figs 1-2). **Source: 1 - Personal data; 2 - Amelichev, 2008; 3 - Amelichev \& Klimchuk, 2010; 4 - Brauner, 1911; 5 - Denisova \& Amelichev, 2005; 6 - Godlevskaya et al., 2009; 7 - Konstantinov et al., 1976; 8 - Lebedev, 1912; 9 - Lebedev, 1914; 10 - Matyushkin, 2010a; 11 - Matyushkin, 2010b; 12 - Matyushkin, 2012; 13 - Turbanov et al., 2015. 
Table 2. List of shelters of Horseshoe bats in artificial underground structures of the Sevastopol City with original data.

\begin{tabular}{|c|l|c|c|}
\hline No & Shelter & R. hipposideros & R. ferrumequinum \\
\hline 33. & $\begin{array}{l}\text { The abandoned tunnel and lift } \\
\text { shaft of the "Caravella" }\end{array}$ & - & $20.07 .2017-4$ ind. [1] \\
\hline 34. & Fort "South Balaklava" & $31.07 .2017-1$ ind. [1] & - \\
\hline 35. & $\begin{array}{l}\text { Reserve object of the Russian } \\
\text { Black Sea Fleet ("Object 221") }\end{array}$ & - & $5.07 .2017-6$ ind. [1] \\
\hline 36. & $\begin{array}{l}\text { 19th coastal battery (Battery } \\
\text { "Drapushko") }\end{array}$ & $31.07 .2017-1$ ind. [1] & $31.07 .2017-1$ ind. [1] \\
\hline 37. & $\begin{array}{l}\text { The unfinished atomic bomb } \\
\text { shelter of the Russian Black Sea } \\
\text { Fleet (Object Kvadraty) }\end{array}$ & - & $10.07 .2017-2$ ind. [1] \\
\hline 38. & $\begin{array}{l}\text { Abandoned excavations in } \\
\text { Chomutovaya gully }\end{array}$ & - & $10.07 .2017-1$ ind. [1] \\
\hline 39. & $\begin{array}{l}\text { Watershed galleries in the park } \\
\text { "Maksimova Dacha" }\end{array}$ & - & $10.07 .2017-1$ ind. [1] \\
\hline
\end{tabular}

Notes and source corresponds to that in Table 1.

40 individuals per site, although such clusters can contain up to 50-200 individuals (Ivanitsky \& Smirnov, 2016). Mating in $R$. hipposideros in south-western Crimea occurs in autumn (Matyushkin, 2010b, 2012), possibly also throughout winter (original unpublished data). Newborns appear mainly in the first ten days of July (Konstantinov et al., 1976; original unpublished data). These phenological observations agree with those, for example, known from western Transcaucasia (Ivanitsky, 2015).

Wintering $R$. hipposideros in the study region are only known from caves and at least some maternity colonies are also located in dungeons. This allows us to attribute this species to troglophiles closely associated with caves.

Rhinolophus ferrumequinum. At present, 34 shelters of $R$. ferrumequinum have been found in southwestern Crimea, including 25 natural and 6 artificial dungeons of Sevastopol, as well as 3 caves in the adjacent territories of the Bakhchisaray District (Tabs 1-3, Figs 2, 3B).

Hibernation of this species has been documented within the three caves - Eldorado (Denisova \& Amelichev, 2005), Zhemchuzhnaya and Villyaburunskaya (original unpublished data). We have been the first to record a breeding colony $R$. ferrumequinum in southwestern Crimea. It was a cluster of 25-30 pregnant females located in the Langa-Kaya-Koba Cave, some of them were already with newborns. Possibly the summer report by Amelichev (2008) of 20-30 individuals in the Skelskaya Cave is to be referred to a nursery colony as well, but this remains uncertain, since it was accompanied by data on neither the sex and age composition of this colony nor on their reproductive status of adults. Winter shelters of $R$. ferrumequinum in southwestern Crimea contained 2-7 individuals per site.
As part of our regular monitoring, from April 29th to July 30th of 2017, in 30 natural and artificial dungeons of Sevastopol and the Bakhchisaray District of the Republic of Crimea, 42 individuals of $R$. hipposideros and $82 R$. ferrumequinum specimens were counted. In addition, during the same observation period representatives of the bat family Vespertilionidae were also found in the same shelters: Plecotus auritus (Linnaeus, 1758), Barbastella barbastellus (Schreber, 1774), as well as small mouse-eared bats, Myotis gr. mystacinus.

Problems of the conservation of Horseshoe bats in south-western Crimea. Declining numbers of bats in the caves of Sevastopol and adjacent territories is increasingly evident. At present, no large colonies of bats numbering 100 or more individuals have been traced in south-western Crimea. However, based on huge deposits of guano in some dungeons, for example, such as we noted in the Kara-Koba Cave in the Tshernaya River canyon, and considering some literature reports, in particular one on a large bat colony that existed for many years in the Partizanskaya Cave, Murkum-Ulle Mountain Ridge, Sukhaya Rechka River valley (Dushevsky \& Stenko, 1986), we can assume that large clusters of bats did live in the study region in the past.

Given the weak reproductive potential and special sensitivity of Horseshoe bats to negative impacts at the northern periphery of the range, including south-western Crimea, the limiting natural and anthropogenic factors are critical to the distribution and abundance of these animals.

There are not many natural enemies to Crimean horseshoes; these include the Eagle Owl (Bubo bubo), the Grey Owl (Strix aluco) and the Leopard Coluber (Zamenis situla) (Abelentsev et al., 1956; Bednarskaya 
Table 3. List of shelters of Horseshoe bats in caves of the Republic of Crimea, along the borders with Sevastopol City with original data.

\begin{tabular}{|c|c|c|c|}
\hline No & Shelter & R. hipposideros & R. ferrumequinum \\
\hline 40. & Mangupskaya I & 29.04.2017 - 5 ind. [1] & - \\
\hline 41. & Lopata-Koba & - & 1.04.2013-2 ind. [1] \\
\hline 42. & Syundyurlyu & - & $23.10 .2009-1$ ind. [3] \\
\hline 43. & Mal-Koba & Several [9] & - \\
\hline 44. & $\begin{array}{l}\text { Gelektitovaya- } \\
\text { Vesennyaya }\end{array}$ & Apr $1994-1$ ind. [11] & - \\
\hline 45. & Priyut Barsuka & Apr 2008 - Several [11] & - \\
\hline 46. & Raskop Medvezhiy & 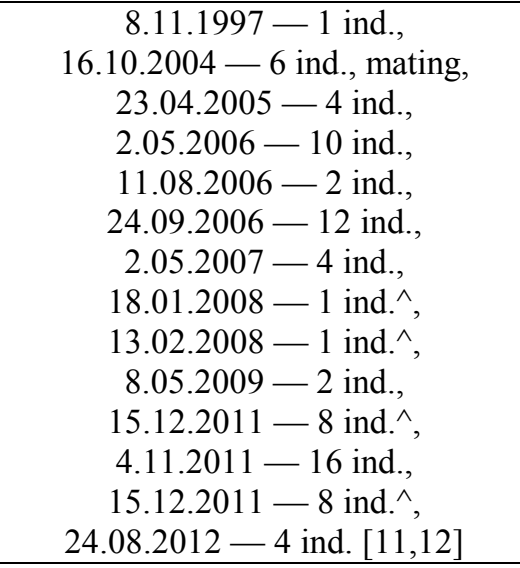 & - \\
\hline 47. & Villyaburunskaya & - & $\begin{array}{c}\text { 2.05.2015-2 ind., } \\
\text { 11.02.2015 - } 3 \text { ind.^, } \\
\text { 16.07.2017- No, fresh } \\
\text { guano[1] }\end{array}$ \\
\hline \multirow{2}{*}{48} & \multirow{2}{*}{ Ayu-Teshik } & $\begin{array}{c}18.04 .1903-?, 2 \text { ind. in coll. ZISP } \\
{[9]}\end{array}$ & \multirow{2}{*}{-} \\
\hline & & $\begin{array}{c}2.05 .2015[1] \\
\text { 16.07.2017- No, fresh guano[1] }\end{array}$ & \\
\hline 49. & $\begin{array}{l}\text { The niches of the cave } \\
\text { settlement Eski-Kermen }\end{array}$ & $29.06 .1960-9$ ind. & - \\
\hline
\end{tabular}

Notes and source corresponds to that in Table 1.

\& Dulitsky, 2015; Turbanov et al., 2015). In the course of our research, a specialized ixodid tick, Ixodes (Eschatocephalus) vespertilionis, was found on Horseshoe bats in the Kara-Koba, Tshernorechenskaya, Skelskaya, Gekkonovaya, Forosskaya, Mangupskaya I, Ayu-Teshik and Villyaburunskaya caves. Some more ectoparasites of Horseshoe bats in Crimea have also been described in a number of special papers (Abelentsev et al., 1956; Vshivkov, 1963; Bobkova, 2003; Ševèík et al., 2011; Orlova \& Orlov, 2018; etc.).

Natural limiting factors also include floods in caves during hibernation. Such situations are described for the caves Kizil-Koba and Yeni-Sala III (Denisova \& Amelichev, 2005). During our research in the MamutTshokrak Cave, four specimens of $R$. hipposideros were found drowned in the winter of 2011-2012, when the water level in the cave changed repeatedly (Fig. 3A).

At the same time, it is obvious that there are anthropogenic factors that render the strongest impact on the troglophilic bats of south-western Crimea, including horseshoe bats. The main is the loss of habitats (1. Habitat Loss) because of shelter troubling due to man's activities (1.3.3. Tourism). We use the IUCN Red List of Threatened Species (Version 2014.3) criteria to characterize the types of anthropogenic factors (see Appendix 2). Especially tragic consequences of troubling the Horseshoe bat shelters are during hibernation, when the animals are forced to spend precious energy for awakening. In additional, a significant negative impact on the condition of a population disturbed during the birth and feeding of offspring is caused through the death of flightless juvenile bats falling down during the inevitable turmoil. Ironically, childbirth occurs in the summer months, when visits to caves increase several times. Eventually, the disturbance factor leads to the loss of the cave as a refuge suitable for the life of bats and, as a consequence, the loss of the entire chain of organisms associated with bats and products of their vital activity. 

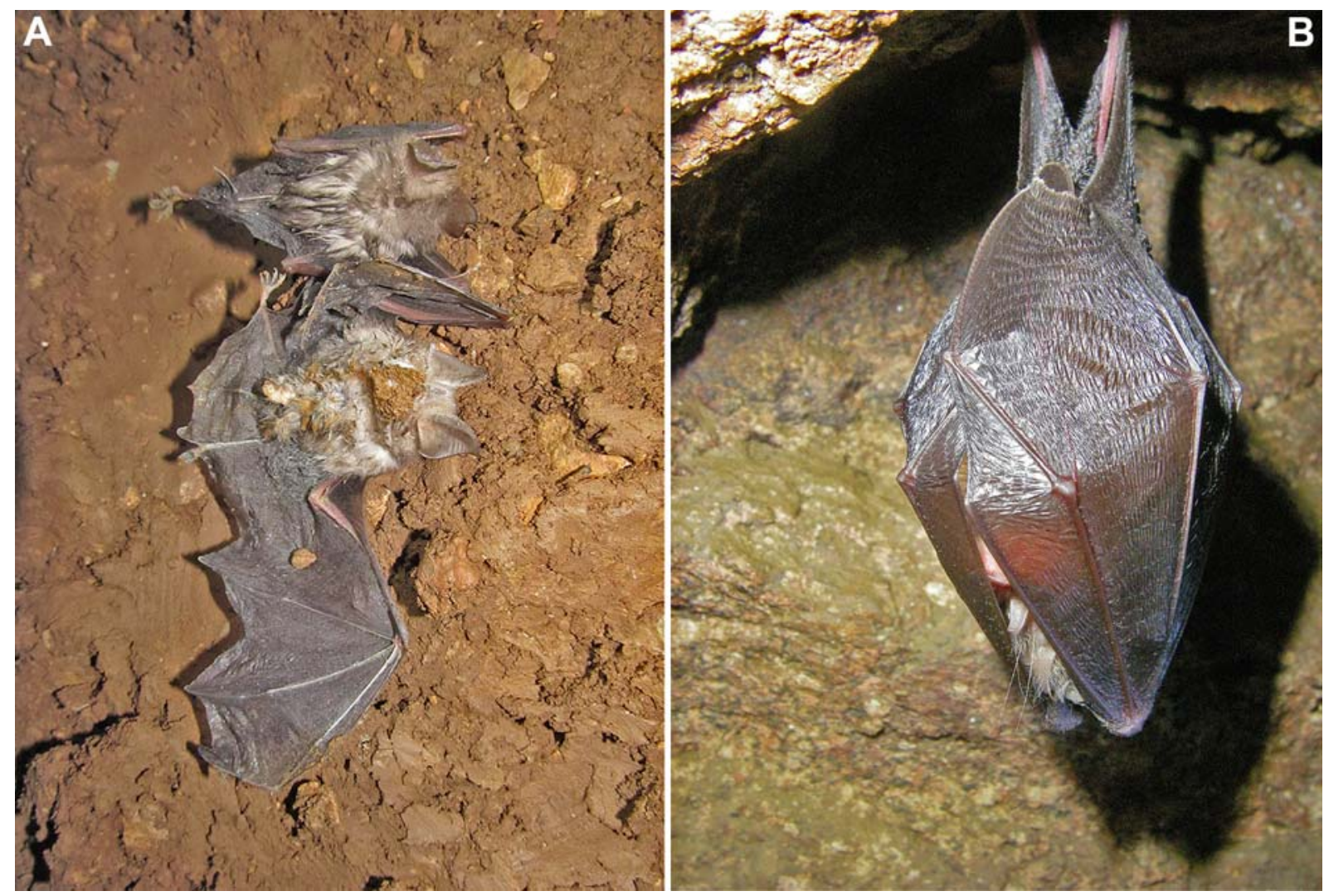

Fig. 3. Common views of the bats: A - Lesser Horseshoe bats (R. hipposideros) drowned in the Mamut-Tshokrak Cave; B Great Horseshoe bat ( $R$. ferrumequinum) live in the Skelskaya Cave. Photographed by Ilya S. Turbanov.

It is very difficult to completely exclude the factor of disturbance. In order to implement some activities to neutralize this threat, a whole set of measures is required. It is necessary to conduct explanatory work among speleologists and diggers about the rules of behaviour in caves where horseshoe and other species of bats live. It is important to normalize visiting excursion caves, while in individual caves, which are the most important for horseshoe bats, we recommend to limit the penetration of visitors by installing an iron antivandal grille at the entrance. In addition, it is necessary to limit the dissemination of information on the exact location of the entrance to caves inhabited by Horseshoe bat colonies.

In addition to the protection of Horseshoe bat shelters, measures are also necessary to conserve the animals themselves, primarily eco-education and legislative nature. Rhinolophus hipposideros and R. ferrumequinum are rare and vulnerable species of bats, both included into the Federal (Panyutin \& Borissenko, 2001; Panyutin \& Kruskop, 2001) and regional Red Data Books, the Republic of Crimea (Bednarskaya \& Dulitsky, 2015; Beskaravayny, 2015) and Sevastopol (Order No. 66 dated May 11, 2016 "On the approval of lists of objects of flora and fauna, fungi included in the Red Data Book of the Sevastopol City").

Protected nature reserve areas (PAs) in the region could also play their roles in the conservation of Horse- shoe bats. Within Sevastopol, Horseshoe bats have been identified in the following PAs: the landscape reserves of national importance "Baydarskiy" and "Cape Aya", the hydrological nature monument of regional significance "Coastal aquatic complex at Cape Fiolent", and the nature park of regional importance "Maksimova Dacha".

\section{Conclusion}

At present, 24 and 34 shelters and roosts of $R$. hipposideros and $R$. ferrumequinum, respectively, have been recorded in south-western Crimea, respectively. In the study region, both species occur throughout the year, being represented there both by wintering and maternity colonies. We have confirmed the reproduction of $R$. ferrumequinum at Sevastopol for the first time. Information on the condition of the populations of Horseshoe bats, as well as an analysis of anthropogenic and natural threats, reaffirms to the need for active measures to be taken in order conserve these animals in the region.

\section{Acknowledgments}

This research of Ilya S. Turbanov was performed in the framework of the state assignment of FASO Russia (themes No. AAAA-A18-118012690106-7, AAAA- 
A18- 118012690105), supported in part by RFBR (project No. 17-54-40017 Abh a) and Main Department of Natural Resources and Ecology of the city of Sevastopol (Sevprirodnadzor) (State contract No. 32/ 17 , dated July 18, 2017, for monitoring the state of wildlife objects listed in the Red Data Book of the Sevastopol City, including monitoring their shelters). The authors are sincerely grateful to all Crimean speleologists and spelestologist who helped us at all stages of the study. Special thanks go to Dr. Sergei I. Golovatch (Moscow, Russia) for editing the English of an advanced draft, and Dr. Alex V. Borissenko (Ontario, Canada) for reviewed our manuscript and contributed to its improvement.

\section{References}

Abelintsev V.I., Pidoplichko I.G. \& Popov B.M. 1956. [Order Chiroptera, or bats - Chiroptera]. Bilanovskiy I.D. et al. (eds.) Fauna of Ukraine. Vol. 1(1). Mammals. Kiev: Academy of Sciences of the Ukrainian SSR Publishing. P.229-446 [in Ukrainian].

Amelichev G.N. 2008. [Skelskaya Cave: State of art of the study, problems of protection and use] // Speleology and karstology. Vol.1. P.94-99 [in Russian, with English summary].

Amelichev G.N. \& Klimchuk A.B. 2010. [Cave Syundyurlyu: the history of research, the ecological state and problems of protection] // Priroda. Vol.61. No.1. P.10-19 [in Russian].

Bednarskaya E.V. \& Dulitsky A.I. 2015. [The Great horseshoe bat Rhinolophus ferrumequinum (Schreber, 1774)] // Ivanov S.P. \& Fateryga A.V. (eds.) The Red Data Book of the Republic of Crimea. Animals. Simferopol: LLC "IT Arial". P.370 [in Russian].

Benda P., Ivanova T., Horáček I., Hanák V., Červený J., Gaisler J., Gueorguieva A., Petrov B. \& Vohralík V. 2003. Bats (Mammalia: Chiroptera) of the eastern Mediterranean. Part 3. Review of bat distribution in Bulgaria. // Acta Societatis Zoologicae Bohemicae. Vol.67. No.4. P.245-357.

Beskaravayny M.M. 2015. [Lesser horseshoe bat Rhinolophus hipposideros (Bechstein, 1800)] // Ivanov S.P. \& Fateryga A.V. (eds.) The Red Data Book of the Republic of Crimea. Animals. Simferopol: LLC “IT Arial”. P.371 [in Russian].

Bobkova O.A. 2003. [Distribution of ixodid ticks (Ixodoidea: Parasitiformes) - ectoparasites of bats (Chiroptera) in Ukraine] // Vestnik Zoologii. Vol.37. No.6. P.23-28 [in Russian, with English summary].

Brauner A.A. 1911. [Bats of the Crimea] // Notes of the Crimean Society of Naturalists and Nature Lovers. Vol.1. P.1-13 [in Russian].

Csorba G., Ujhelyi P. \& Thomas N. 2003. Horseshoe bats of the world (Chiroptera: Rhinolophidae). Shropshire: Alana Books, Bishop's Castle. 160 p.

Denisova E.V. \& Amelichev G.N. 2005. [Ecological features of cave shelters of the Crimea's chiropterofauna] // Bokov V.A., Gol'din P.E., Dulitsky A.I., Ena A.V., Prokopov G.A., Rudyk A.N. \& Temirova S.I. (eds.) Materials of III scientific conference "Zapovedniki Kryma: zapovednoe delo, bioraznoobrazie, ekoobrazovanie". Part II. Zoologiya bespozvonochnykh. Zoologiya pozvonochnykh. Ekologiya. Simferopol: KRA "Ecology and Peace". P.126130 [in Russian].

Dietz C., Von Helversen O. \& Nill D. 2009. Bats of Britain, Europe and Northwest Africa. London: Black Publisers Ltd. 400 p.

Dulitsky A.I. \& Kovalenko I.S. 2003. [Materials on the bats of Crimea in the zoological collections of Ukraine and Russia] // Voprosy razvitiya Kryma. Vol.15. P.197-210 [in Russian].

Dushevsky V.P. \& Stenko R.P. 1987. [Bats of karst cavities of the Mountainous Crimea and questions of their protection] // Klimchyuk A.B. (ed.). Abstracts of the V AllUnion Conference of Speleology and Karstology "Problemy izucheniya, ekologii i okhrany peshcher". Kiev: Kiev. P.117-118 [in Russian].

Dulitsky A.I., Mikhailova A.E. \& Stenko R.P. 2001. [The first records the Mediterranean and Mehely's horseshoe bats (Rhinolophus mehelyi Matschie, 1901 and R. euryale Blasius, 1853; Chiroptera; Rhinolophidae) in the territory of Ukraine] // Dulitsky A.I., Popov V.N., Ena A.V. \& Artov A.M. (eds.) Materials of republican conference "Zapovedniki Kryma na rubezhe tysyacheletiy". Simferopol: Simferopol. P.32-34 [in Russian].

Gazaryan S.V. 2007. [New records of the Mediterranean horseshoe bat Rhinolophus euryale from Russia] // Plecotus et al. Vol.10. P.47-50 [in Russian, with English summary].

Gazaryan S.V. \& Ivanitsky A.N. 2005. [On the faunal and taxonomic status of the Mediterranean horseshoe bat Rhinolophus euryale in the West Transcaucasia] // Plecotus et al. Vol.8. P.54-61 [in Russian, with English summary].

Godlevskaya E.V., Ghazali M.A. \& Postawa T. 2009. [Current state of troglophilic bats (Mammalia, Chiroptera) of the Crimea] // Vestnik zoologii. Vol.43. No.3. P.253265 [in Russian, with English summary].

Ivanitsky A.N. 2015. To biology and phenology of troglophilous bats of Abkhazia // Plecotus et al. Vol.18. P.2633 [in Russian, with English summary].

Ivanitsky A.N. 2017. [Ecological and faunistic characteristics of bats (Chiroptera) of the fauna of Abkhazia and adjacent territories]. Avtoreferat na soiskanie uchenoi stepeni kandidata biologicheskikh nauk. Tolyatti. 19 p. [in Russian]

Ivanitsky A.N. \& Smirnov D.G. 2016. [Horseshoe bats (Rhinolophidae, Chiroptera) of Abkhazia and adjacent territories: distribution, wintering, reproduction] // University Proceedings. Volga Region. Natural Sciences. Vol.1. P.3-13 [in Russian, with English summary].

Heymer A. 1964. Résultats du baguage de chauves-souris dans les Pyrénées-orientales de 1945, 1959 // Vie et Milieu. Série A. Vol.15. No.3. P.765-799.

Konstantinov A.I., Vshivkov F.N. \& Dulitsky A.I. 1976. [Current state of fauna of bats of the Crimea] // Zoologicheskii Zhurnal. Vol.55. No.6. P.885-892 [in Russian, with English summary].

Lebedev N.D. 1912. [Caves of Crimea] // Notes of the Crimean-Caucasian Mountain Club. Vol.2. No.1. P.212 [in Russian]. 
Lebedev N.D. 1914. [Crimean caves and their fauna] // Zapiski Krymsko-Kavkazskogo gornogo kluba. Vol.2. No.2. P.3-28 [in Russian].

Matyushkin B. 2010a. [Studies in the cave of Karan-Koba] // Svet. Vol.36. No.1. P.44-45 [in Russian].

Matyushkin B. 2010b. [From the detachment of tailed amphibians] // Svet. Vol.36. No.1. P.48-52 [in Russian].

Matyushkin B. 2012. [Observation of the centipede-bone of the order Lithobiomorpha (Myriapoda, Chilopoda) in the caves of the Ai-Petri massif (Mountain Crimea)] // Svet. Vol.38. No.1. P.98-107 [in Russian].

Nagy Z.L. \& Postawa T. 2010. Seasonal and geographical distribution of cave-dwelling bats in Romania: implications for conservation // Animal Conservation. Vol.14. P.1-13.

Orlova M.V. \& Orlov O.L. 2018. [Contribution to the bat ectoparasite fauna (Chiroptera: Vespertilionidae, Rhinolophidae) of Crimea] // Parazitologiya. Vol.52. No.2. P.110-117 [in Russian].

Panyutin K.K. \& Borissenko A.V. 2001. [Lesser horseshoe bat - Rhinolophus hipposideros (Bechstein, 1800)] // Danilow-Daniljan V.I. et al. (eds.) Red Data Book of the Russian Federation (Animals). Moscow: AST \& Astrel'. P.607-608 [in Russian].

Panyutin K.K. \& Kruskop S.V. 2001. [The Great horseshoe bat - Rhinolophus ferrumequinum (Schreber, 1774)] // Danilow-Daniljan V.I. et al. (eds.) Red Data Book of the Russian Federation (Animals). Moscow: AST \& Astrel'. P.609-610 [in Russian].
Rakhmatulina I.K. 2005. [Bats of Azerbaijan (fauna, ecology, zoogeography)]. Baku: Institute of Zoology of NAS of Azerbaijan. 480 p. [in Russian]

Ševèík M., Benda P. \& Uhrin M. 2011. First records of the bat fly Phthiridium biarticulatum (Diptera: Nycteribiidae) in Crimea // Vespertilio. Vol.15. P.159-160.

Simmons N.B. 2005. Order Chiroptera // Wilson D.E. \& Reeder D.M. (eds.). Mammal Species of the World. Baltimore: Johns Hopkins University Press. Vol.1. P.325529.

Turbanov I.S., Oksinenko P.V. \& Kukushkin O.V. 2015. [On the findings of reptiles in the karst cavities of the Mountain Crimea] // Turbanov I.S., Marin I.N. \& Gongalsky K.B. (eds.) Proceedings of the All-Russian Youth Conference "Biospeleologiya Kavkaza i drugikh rayonov Rossii” (Moscow, December 3-4, 2015). Kostroma: Kostroma Printing House. P.90-94 [in Russian, with English summary].

Vshivkov F.N. 1963. [Gamazic mites of bats of Crimea] // Pogrebn L.P. (ed.) Materials of the IV Conference of parasitologists of the Ukrainian SSR "Problems of Parasitology". Kiev: Academy of Sciences of the Ukrainian SSR. P.324-326 [in Russian].

Zagorodniuk I.V. 1999. Taxonomy, biogeography and abundance of the horseshoe bats in the Eastern Europe // Acta Zoologica Cracoviensia. Vol.42. No.3. P.407-421.

Appendix 1. Internet-source is used for searching of caves and grottoes within territory of the Sevastopol City and the neighbouring Bakhchisaray District of the Republic of Crimea.

Web-resource "The information retrieval system "Caves", https://speleoatlas.ru

Appendix 2. Internet-source is used for assessment of criteria and characteristics of types of anthropogenic impact on the Horseshoe bats.

Web-resource "The IUCN Red List of Threatened Species", http://www.iucnredlist.org 